\title{
Investigation of the structure and localization of the urease of Helicobacter pylori using monoclonal antibodies
}

\author{
P. R. Hawtin, ${ }^{1 *}$ A. R. StaceY ${ }^{2}$ and D. G. NeWell ${ }^{2}$ \\ ${ }^{1}$ PHLS, Southampton General Hospital, Tremona Road, Southampton SO9 4XY, UK \\ ${ }^{2}$ PHLS, Centre for Applied Microbiology and Research, Porton Down, Salisbury SP4 OJG, UK
}

(Received 9 February 1990; revised 15 June 1990; accepted 4 July 1990)

\begin{abstract}
The urease of Helicobacter pylori (formerly Campylobacter pylori) has been partly purified by fast protein liquid chromatography. This material contained $10 \mathrm{~nm}$ doughnut-like structures when examined by electron microscopy and comprised three major polypeptides $(61 \mathrm{kDa}, 56 \mathrm{kDa}$ and $28 \mathrm{kDa})$. Only two of these polypeptides $(61 \mathrm{kDa}$ and $28 \mathrm{kDa}$ ) were observed in urease-containing material isolated by preparative non-denatured PAGE. Monoclonal antibodies (mAbs) were produced which were directed against two of these polypeptides (56 kDa and $28 \mathrm{kDa}$ ). Only mAbs directed against the $28 \mathrm{kDa}$ polypeptide inhibited or captured urease activity. These results suggest that the $56 \mathrm{kDa}$ polypeptide is not essential for enzyme activity. Anti-urease mAbs were used in an indirect immunogold technique to localize the enzyme at the ultrastructural level. In both prefixed bacteria and ultrathin cryosectioned bacteria the enzyme was located on the cell surface and in material apparently shed from that surface.
\end{abstract}

\section{Introduction}

Helicobacter pylori (previously Campylobacter pylori) is a Gram-negative spiral organism which colonizes the gastric mucosa of humans, non-human primates and pigs. A close correlation between the presence of this bacterium, gastritis and peptic ulceration is now well established (Blaser, 1987). Although, the pathogenic role of this organism in gastritis is now accepted, the mechanisms of pathogenicity are undefined.

A significant host immune response to $H$. pylori has been demonstrated by various methods. This serological response has been exploited to develop assays for the non-invasive diagnosis of $\boldsymbol{H}$. pylori infections and for epidemiological surveys (Newell \& Rathbone, 1989). As gastritis is essentially the recruitment of immunocompetent cells into the gastric mucosa, apparently in response to foreign antigen, it is important, therefore, to identify those antigens which induce dominant and specific reactions by the host.

The production of a urease of high activity is a characteristic of $\boldsymbol{H}$. pylori and antibodies are produced against urease-containing material during infection (Newell \& Rathbone, 1989). The pathogenic role of this enzyme is unknown, but Hazell \& Lee (1986) have suggested a complex back diffusion model involving

\footnotetext{
Abbreviations: FPLC, fast protein liquid chromatography; mAb, monoclonal antibody.
}

ammonia production by the urease, while Marshall et al. (1988) ascribed its role to protecting the bacteria in the acid environment of the stomach.

In this study a panel of monoclonal antibodies (mAbs) was produced to allow the investigation of the structure and antigenicity of the enzyme using Western blotting, enzyme capture and inhibition of the urease activity. In addition, the location of the urease in $H$. pylori was determined by immunolabelling techniques at the ultrastructural level.

\section{Methods}

Bacterial strains. H. pylori strain NCTC 11638 was isolated by Dr B. Marshall and kindly supplied by Dr M. B. Skirrow. All other strains were isolated from gastric biopsies by direct culture on blood agar [ $2 \%$ (v/v) blood agar base no. 2] containing $5 \%(\mathrm{v} / \mathrm{v})$ defibrinated, lysed horse blood with Skirrow's antibiotics (Skirrow, 1977), incubated at $37^{\circ} \mathrm{C}$ in microaerobic conditions. Strains were stored in $10 \%(\mathrm{v} / \mathrm{v})$ glycerol in $1 \%(\mathrm{w} / \mathrm{v})$ proteose peptine in liquid nitrogen.

Sonicated antigen preparation. Bacteria were harvested, from $48 \mathrm{~h}$ lawned agar plate cultures, into sterile distilled water and subjected to three $30 \mathrm{~s}$ bursts of sonication ( $10 \mu \mathrm{m}$ amplitude: MSE Soniprep) interrupted by $30 \mathrm{~s}$ cooling periods. This crude sonicate was then centrifuged for $5 \mathrm{~min}$ at $11000 \mathrm{~g}$ and the supernatant fraction passed through a $0.2 \mu \mathrm{m}$ filter to give a sonicated antigen preparation.

Acid-extracted antigen preparation. Acid extracts of whole organisms were prepared by incubation in $0.2 \mathrm{M}$-glycine/ $\mathrm{HCl}$ buffer, $\mathrm{pH} 2.2$, as previously described (Newell et al., 1984). 
Outer membrane preparation. Outer membranes of $\boldsymbol{H}$. pylori were prepared by solubilization of crude membranes preparations with sodium $N$-lauroyl sarcosinate as previously described (Newell et al., 1984).

Fast protein liquid chromatography (FPLC). H. pylori proteins were separated by size exclusion gel filtration. Whole-cell sonicate $(200 \mu l$ of $20 \mathrm{mg}$ protein $\mathrm{ml}^{-1}$ ) was applied to a Superose 6 FPLC column (Pharmacia) equilibrated in phosphate-buffered saline (PBS; $140 \mathrm{~mm}$ $\mathrm{NaCl}, 2.7 \mathrm{~mm}-\mathrm{KCl}, 8 \mathrm{~mm}-\mathrm{Na}_{2} \mathrm{HPO}_{4}$ and $1.5 \mathrm{~mm}-\mathrm{KH}_{2} \mathrm{PO}_{4}, \mathrm{pH} 7.2$ ). Fractions $(1 \mathrm{ml})$ were collected at a rate of $0.5 \mathrm{ml} \mathrm{min}^{-1}$. Fractions were screened for urease activity by adding $10 \mu \mathrm{l}$ of the fraction to $10 \mu \mathrm{l}$ $100 \mathrm{mM}$-urea with $0 \cdot 2 \%(\mathrm{w} / \mathrm{v})$ phenol red as described by Mobley $e t$ al. (1988). Urease-positive fractions produced an intense red coloration. The titre of the enzyme in each fraction was measured by double diluting, in PBS, $100 \mu$ of the fraction starting at $1: 10$ dilution and incubating at room temperature with $100 \mu 100 \mathrm{mM}$-urea with $0 \cdot 2 \%$ $(w / v)$ phenol red. The end point was taken as the highest dilution showing colour change from yellow to red within $1 \mathrm{~min}$. The column was calibrated for molecular mass using high molecular mass standards (Pharmacia).

$S D S-P A G E$. Linear gradient $(10-25 \%$, w/v) SDS-PAGE was done as described by Lambden et al. (1979) and the protein profiles visualized by Coomassie brilliant blue staining. Relative molecular masses were estimated from standards (Sigma) containing $\alpha$-lactalbumin, trypsin inhibitor, trypsinogen, carbonic anhydrase, glyceraldhyde-3-phosphate dehydrogenase, egg albumin and bovine serum albumin.

Non-denaturing $P A G E$. Linear $(5 \%, \mathrm{w} / \mathrm{v})$ acrylamide gels were prepared as described by Johnstone \& Thorpe (1987). Samples were prepared in $50 \%(\mathrm{w} / \mathrm{v})$ sucrose $/ 0.1 \%(\mathrm{w} / \mathrm{v})$ bromophenol blue and electrophoresed at $100 \mathrm{~V}$ for $19 \mathrm{~h}$ at $4^{\circ} \mathrm{C}$. The urease band was detected by a urea overlay technique and phenol red staining (Mobley $e t$ al., 1988). The urease-containing band was cut out, homogenized in $100 \mu \mathrm{l}$ dissociation buffer and denatured for SDS-PAGE.

$m A b$ production. F1 (BALB/c $\times$ CBA) mice were primed subcutaneously with outer membrane preparation, acid extract or the urease fraction $(20 \mu \mathrm{g}$ protein in Freund's complete adjuvant), then boosted twice $(20 \mu \mathrm{g}$ protein in incomplete adjuvant) at two weekly intervals. A final boost ( $20 \mu \mathrm{g}$ aqueous protein) was administered, intravenously, $3 \mathrm{~d}$ before the fusion.

Immune spleen cells were fused with NS1 myeloma cells using PEG (Newell et al., 1988). Hybridoma culture supernatant fluids were screened by ELISA, initially against sonicated antigen preparation then against the urease fraction (see below). Positive hybridomas were cloned twice. Ascitic fluid was obtained by introducing hybridoma cells, via intraperitoneal inoculation, into mice pretreated with pristane. Purification of ascitic fluid was by ion-exchange chromatography (Newell et al., 1988). The mAbs produced were isotyped using rabbit anti-mouse immunoglobulin class and subclass antibodies coupled to biotin (Amersham) in an indirect ELISA.

ELISA. Whole cell sonicate $\left(100 \mu \mathrm{l}\right.$ at $\left.10 \mu \mathrm{g} \mathrm{ml}^{-1}\right)$ or fraction 14 antigen $\left(100 \mu \mathrm{l}\right.$ at $\left.5 \mu \mathrm{g} \mathrm{ml}^{-1}\right)$ in $0 \cdot 1 \mathrm{M}$-potassium carbonate buffer, pH 9.6, was adsorbed onto 96-well microELISA plates (Dynatech) overnight at $20^{\circ} \mathrm{C}$. The plates were then washed three times with ELISA wash solution $\left[8.5 \mathrm{~g} \mathrm{NaCl}^{-1 / 0.05 \%}\right.$ (v/v) Tween 20]. Hybridoma supernatant fluid (diluted 1 in 2) or ascitic fluid (diluted 1 in 100) diluted in $0.05 \mathrm{M}$-Tris/acetate buffer, $\mathrm{pH} 7.2$, containing $1 \%$ $(w / v)$ bovine serum albumin (ELISA diluent) was added to the wells and incubated for $2 \mathrm{~h}$ at $37^{\circ} \mathrm{C}$. After washing the wells sheep antimouse IgG F $\left(\mathrm{ab}^{\prime}\right)_{2}$ conjugate ( $1: 2000$ in ELISA diluent; Amersham) was added and incubated at $37^{\circ} \mathrm{C}$ for $30 \mathrm{~min}$. Bound peroxidase was detected with the substrate tetramethyl benzidene (TMB) and hydrogen peroxide. The absorbance was measured at $450 \mathrm{~nm}$ after stopping the reaction with $50 \mu \mathrm{l} 2 \mathrm{M}$-sulphuric acid.
Urease-capture ELISA. Anti-urease mAbs $\left(100 \mu \mathrm{l}\right.$ at $\left.10 \mu \mathrm{g} \mathrm{ml}^{-1}\right)$, or an irrelevant control mAb directed against guinea-pig $\mathrm{T}$ lymphocytes (GPA) (McBride \& Newell, 1989), were adsorbed onto microELISA plates as described above. Excess antibody was removed by washing. Sonicated antigen preparation $\left(5 \mu \mathrm{g}\right.$ protein $\left.\mathrm{ml}^{-1}\right)$ in ELISA diluent was added and incubated for $2 \mathrm{~h}$ at $37^{\circ} \mathrm{C}$. Bound urease was detected using urea as substrate, with addition of Berthelot reagents, and the $A_{620}$ was measured (Precious et al., 1987).

Urease inhibition assay. Sonicated antigen preparation $(10 \mu \mathrm{l}$ at $8 \mathrm{mg}$ $\mathrm{ml}^{-1}$ ) was incubated with $10 \mu \mathrm{lmAb}$ ascitic fluid $(1: 100$ dilution) for $1 \mathrm{~h}$ at $37^{\circ} \mathrm{C}$. An irrelevant mAb (GPA) was used as control. The mixture $(10 \mu \mathrm{l})$ was then added to $1 \mathrm{ml} 5 \mathrm{mM}$-urea in $3 \mathrm{mM}$-sodium phosphate buffer, $\mathrm{pH} 6.8$, containing $0.02 \%(\mathrm{w} / \mathrm{v})$ phenol red. The rate of colour development was measured at $560 \mathrm{~nm}$ over a $5 \mathrm{~min}$ incubation period.

Electroimmunoblotting. SDS-PAGE gels were blotted as previously described (Newell, 1987a). The nitrocellulose blots were blocked in $3 \%$ $(\mathrm{w} / \mathrm{v})$ gelatine in $200 \mathrm{mM}$-Tris/HCl buffer, $\mathrm{pH} 7.5$, containing $500 \mathrm{~mm}-$ $\mathrm{NaCl}$ and $0.05 \%(\mathrm{v} / \mathrm{v})$ Tween 20 (TTBS) and incubated with hybridoma supernatant fluids $(1: 2$ dilution) or ascitic fluid $(1: 100$ dilution) diluted in TTBS containing $1 \%(\mathrm{w} / \mathrm{v})$ gelatine. The blots were washed with TTBS and incubated with peroxidase-conjugated goat anti-mouse IgG $\mathrm{F}\left(\mathrm{ab}^{\prime}\right)_{2}$ (diluted $1: 2000$ in TTBS with $1 \%(\mathrm{w} / \mathrm{v})$ gelatine; Amersham) for $1 \mathrm{~h}$ at room temperature with constant agitation. The blots were washed in TTBS with a final wash in TTBS without the Tween 20 . Bound conjugate was detected by incubation with amino ethyl carbazole as the substrate (Newell et al., 1988).

Immunogold-labelling. Bacteria were prefixed in $0.1 \%$ glutaraldehyde, in $0.1 \mathrm{M}$-sodium phosphate buffer, $\mathrm{pH} 7.2$, for $10 \mathrm{~min}$ at room temperature, washed three times in PBS and incubated with mAb ( $1: 100$ dilution of ascitic fluid in PBS) for $2 \mathrm{~h}$ at $37^{\circ} \mathrm{C}$ with constant agitation. After washing three times, by cycles of suspension and centrifugation, the organisms were adsorbed onto Formvar-carboncoated copper grids before incubation, by flotation, on $100 \mu l$ droplets of goat anti-mouse IgG coupled to $10 \mathrm{~nm}$ gold particles (Biocell, Cardiff) $[1: 100$ dilution in PBS containing $1 \%(\mathrm{w} / \mathrm{v})$ bovine serum] in a humidified chamber. Unbound gold was removed by washing with PBS. The grids were negatively stained with $0.1 \%(w / v)$ phosphotungstic acid.

For cryostat sections pellets of bacteria were infused with $2.2 \mathrm{M}$ sucrose in PBS at room temperature for $15 \mathrm{~min}$. The material was then mounted onto a microtome stub and snap-frozen in liquid nitrogen. The frozen block was then cut ( $500 \mathrm{~nm}$ sections) with a glass knife at $-100^{\circ} \mathrm{C}$ and collected on Formvar-carbon-coated copper grids. Three sections were then pre-incubated on droplets of $1 \%(\mathrm{w} / \mathrm{v})$ ovalbumin (Sigma) in PBS (PBSO) for $1 \mathrm{~h}$ at room temperature. The sections were then incubated with mAb (1:100 dilution in PBSO) for $1 \mathrm{~h}$ at room temperature. After washing in PBSO for $1 \mathrm{~h}$, the sections were incubated with goat anti-mouse IgG coupled to $10 \mathrm{~nm}$ gold particles for $1 \mathrm{~h}$ at room temperature. The sections were washed in PBSO three times, once in PBS and rinsed in glass distilled water. The sections were immersed in $2 \%(\mathrm{w} / \mathrm{v})$ aqueous methylcellulose as a mountant and stained with $0.3 \%(\mathrm{w} / \mathrm{v})$ aqueous uranyl acetate.

All specimens were examined using an Hitachi 7000 transmission electron microscope.

\section{Results}

\section{Purification and characterization of urease}

The urease activity of sonicated antigen preparation of $H$. pylori, when separated by FPLC gel filtration, was concentrated in fractions 14 and 15 (Fig. 1). By 


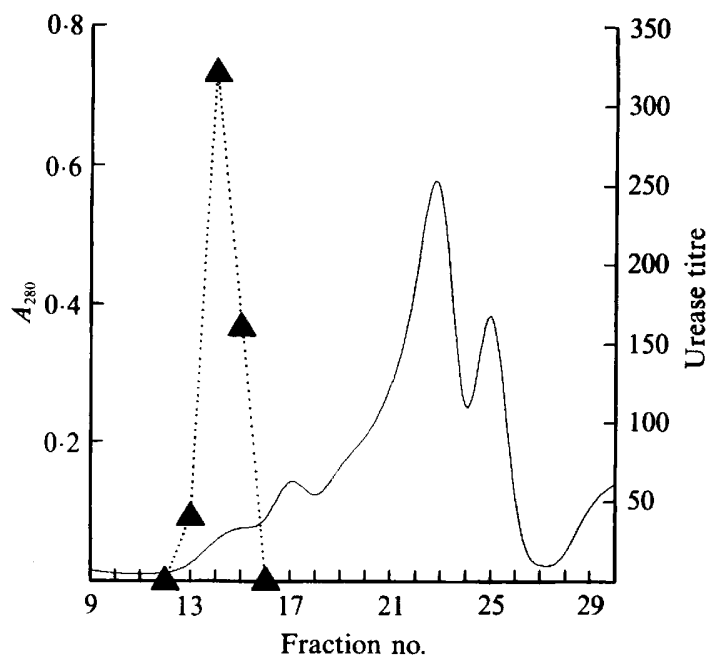

Fig. 1. Fractionation of sonicated antigen preparation by FPLC. Column, Superose 6; elution buffer, PBS, $\mathrm{pH} 7.2$; flow rate, $0.5 \mathrm{ml}$ $\mathrm{min}^{-1}$; detector absorption, $280 \mathrm{~nm}$; sample, $4 \mathrm{mg}$ protein sonicated antigen preparation. Fractions of $1 \mathrm{ml}$ were collected and numbered as shown. The urease activity was determined from serial dilutions $(1: 2$ dilution, starting from a 1:10 dilution, in PBS) of each fraction. Equal volumes of the diluted fraction and $100 \mathrm{~mm}$-urea containing $0 \cdot 2 \%(\mathrm{w} / \mathrm{v})$ phenol red were incubated together and the red colour formation, indicating enzyme activity, was determined by eye. The highest dilution to give this coloration, in comparison with a PBS control, was taken as the urease titre $(\cdot \mathbf{\Delta} \cdot \cdot)$.

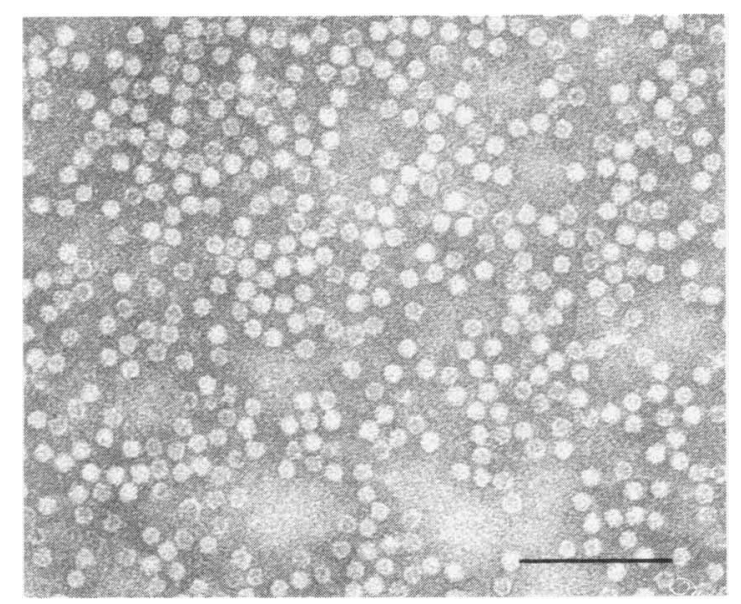

Fig. 2. Transmission electron micrograph of FPLC fraction 14, negatively stained with $0.1 \%$ phosphotungstic acid, $\mathrm{pH}$ 6.0. Note the doughnut-like structures. Bar, $0.1 \mu \mathrm{m}$.

comparison with molecular mass markers separated under identical conditions by the same chromatography column, the molecular mass of the urease was estimated to be $510 \mathrm{kDa}$. Fractions 14 and 15 only contained $10 \mathrm{~nm}$ doughnut-like structures when examined by electron microscopy (Fig. 2). Approximately $5.5 \%$ of the protein loaded onto the column was recovered in fraction 14. By

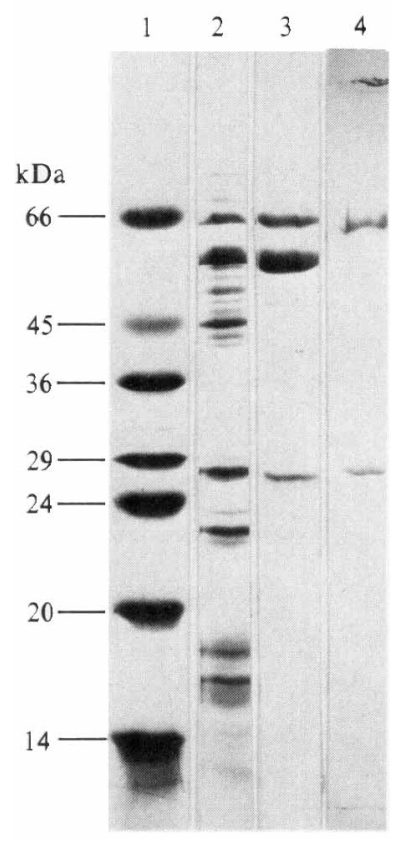

Fig. 3. SDS-PAGE of the sonicated antigen preparation, FPLCfractionated urease and non-denatured PAGE-prepared urease of H. pylori. Lanes: 1, molecular mass markers; 2 , sonicated antigen preparation; 3, FPLC fraction $14 ; 4$, the urease-containing band separated from the sonicated antigen preparation by non-denaturing PAGE, cut out of the gel, homogenized and reduced for SDS-PAGE.

SDS-PAGE the sonicated antigen preparation comprised many polypeptides with major bands of $61 \mathrm{kDa}$, $56 \mathrm{kDa}$ and $54 \mathrm{kDa}$ (Fig. 3, lane 2). In comparison, fraction 14 comprised three major polypeptides of $61 \mathrm{kDa}, 56 \mathrm{kDa}$ and $28 \mathrm{kDa}$ (Fig. 3, lane 3). None of these subunits showed independent enzyme activity.

When the sonicated antigen preparation was separated by non-denaturing PAGE a single band of urease activity was detected by using the substrate overlay technique. This urease band, cut from the non-denaturing gel, when separated by SDS-PAGE comprised only two polypeptides of $61 \mathrm{kDa}$ and $28 \mathrm{kDa}$ (Fig. 3, lane 4).

\section{Production and characterization of $m A b s$}

A panel of monoclonal antibodies was produced that reacted with the urease-containing fractions 14 and 15 by ELISA, but reacted poorly with other FPLC fractions. These mAbs also reacted with outer-membrane preparation and acid-extracted antigen. Ten hybridomas (CP11 to CP20) were selected for further characterization (Table 1). In Western blots of SDS-PAGE of fraction 14, three mAbs immunolabelled the $56 \mathrm{kDa}$ polypeptide, namely CP12, CP20 and CP19 (weak reaction). Each of the remaining mAbs immunolabelled the $28 \mathrm{kDa}$ polypeptide (Fig. 4), although $\mathrm{mAbs} \mathrm{CP} 17$ and $\mathrm{CP} 18$ reacted 


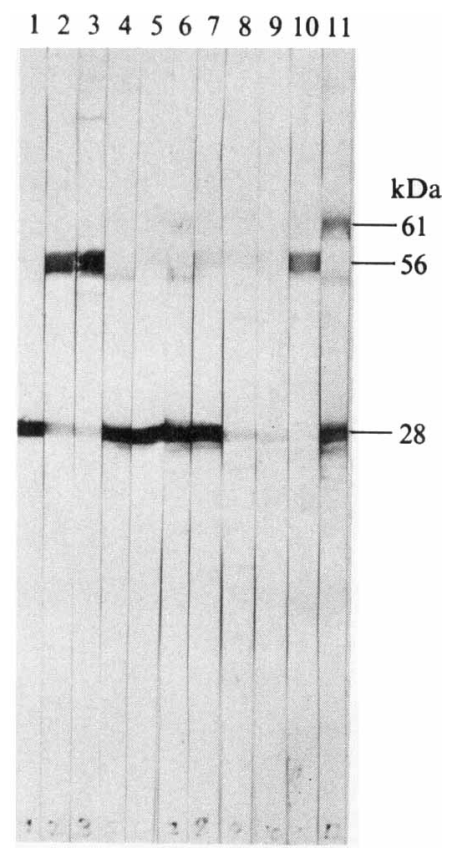

Fig. 4. Western blot of SDS-PAGE of FPLC fraction 14 with a panel of mAbs. Lanes: 1, CP11 ; 2, CP12; 3, CP20; 4, CP14; 5, CP13; 6, CP16; $7, \mathrm{CP} 15 ; 8, \mathrm{CP} 17 ; 9, \mathrm{CP} 18 ; 10, \mathrm{CP} 19 ; 11$, polyclonal mouse antiserum.

Table 1. The isotype and specificity of $m A b$ directed against FPLC fraction 14

\begin{tabular}{lll}
\hline \hline mAb & Isotype & $\begin{array}{c}\text { Subunit } \\
\text { recognized } \\
\text { by mAb (kDa)* }\end{array}$ \\
\hline CP11 & IgG1 & 28 \\
CP12 & ND & 56 \\
CP13 & IgG1 & 28 \\
CP14 & IgG2a & 28 \\
CP15 & IgG1 & 28 \\
CP16 & IgG1 & 28 \\
CP17 & IgG1 & 28 (weak), 18 \\
CP18 & IgG2b & 28 (weak) \\
CP19 & ND & 56 (weak) \\
CP20 & ND & 56 \\
\hline \hline \\
\multicolumn{3}{l}{ ND, Not determined. } \\
*. Molecular mass of polypeptide subunit recog- \\
nized by the mAb in Western blots of SDS-PAGE \\
of fraction 14.
\end{tabular}

very weakly with this polypeptide. All mAbs directed against this polypeptide reacted with the 10 strains of $H$. pylori tested. In Western blots of sonicated antigen preparation separated by non-denaturing PAGE, the mAbs raised against the $28 \mathrm{kDa}$ polypeptide reacted with a single protein band which also demonstrated urease activity detectable on the blot.

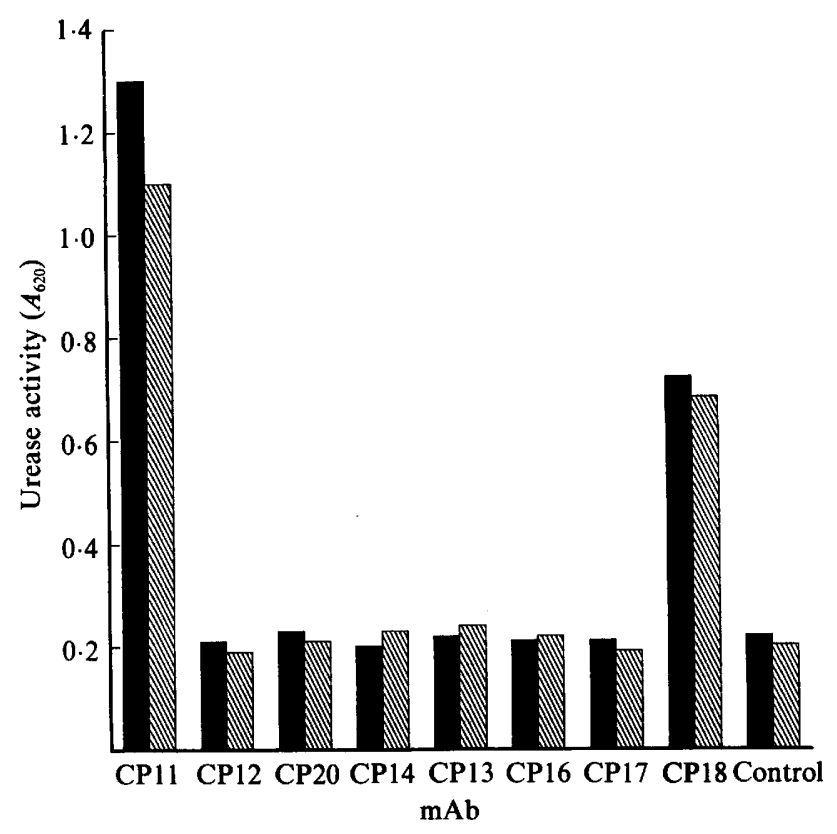

Fig. 5. The capture of urease activity by a panel of mAbs. mAbs were adsorbed onto microELISA plate wells. The bound antibodies were incubated with sonicated antigen preparation. Bound urease activity was detected by incubation with a urea substrate. Liberated ammonia was detected by addition of Berthelot reagents. The $A_{620}$ was measured. Hatched and solid bars show the results of two separate experiments. Each mAb tested is shown and the control was the irrelevant mAb GPA.

The urease activity of the sonicated antigen preparation was reduced by $73 \%$ in the presence of $\mathrm{mAb}, \mathrm{CP} 11$, when compared to the control mAb. CP11 was the only $\mathrm{mAb}$ which inhibited this enzyme activity. This same $\mathrm{mAb}$, and to a lesser extent mAb CP18, also captured urease activity (Fig. 5).

None of the mAbs, that recognized the $56 \mathrm{kDa}$ polypeptide captured or inhibited urease activity. No mAbs were produced that immunolabelled the $61 \mathrm{kDa}$ polypeptide.

\section{Electron microscopy}

The mAb CP11 was used, in an indirect immunogold technique, to locate the urease on prefixed $H$. pylori. The enzyme was identified on the surface-exposed material which appeared to be loosely bound and possibly shed from the organism (Fig. 6a). To determine if there was any intracellular localization of the urease, ultrathin cryostat sections of unfixed bacteria were also immunolabelled. This technique requires the mounting of ultrathin, cryosectioned material in methylcellulose which, unfortunately, does not allow the sharp definition of bacterial morphology. Nevertheless, the clarity was sufficient to determine that once again the antigen was 


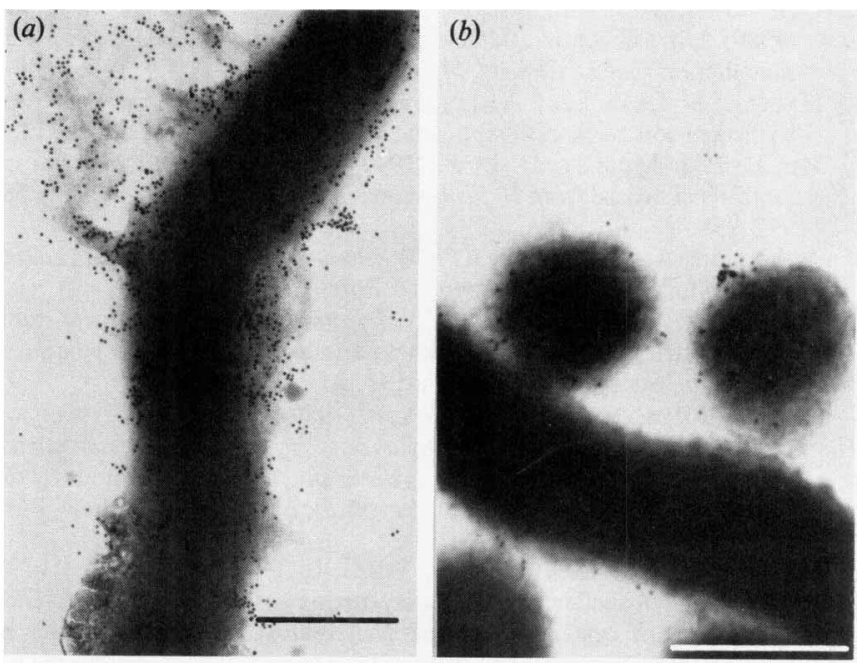

surface-located, closely adjacent to the outer membrane (Fig. 6b). No labelling was observed with the control antibody in either technique.

\section{Discussion}

The urease of $H$. pylori has been partly purified by gel filtration chromatography using FPLC which yielded active enzyme in a native conformational state suitable for immunization. A number of mAbs have been produced against this urease-containing material and used to investigate the structure and localization of the enzyme.

Although the urease-containing FPLC fraction comprised three major polypeptides $(61 \mathrm{kDa}, 56 \mathrm{kDa}$ and $28 \mathrm{kDa}$ ), the evidence from the non-denaturing gels suggested that only two of these polypeptides $(61 \mathrm{kDa}$ and $28 \mathrm{kDa}$ ) were essential to the enzyme activity. These results are in marked contrast to the published evidence of Dunn et al. (1989) who considered, on the basis of two dimensional gel electrophoresis, that $66 \mathrm{kDa}$ and $63 \mathrm{kDa}$ (probably equivalent to our $61 \mathrm{kDa}$ and $56 \mathrm{kDa}$ ) polypeptides were subunit constituents of partly purified urease and that a $31 \mathrm{kDa}$ polypeptide (probably equivalent to our $28 \mathrm{kDa}$ polypeptide) was inconsistently present. We conclude that this anomaly is, as Dunn et al. (1989) suggest, the result of differences in electrophoretic technique. Our evidence suggests that the $61 \mathrm{kDa}$ and the $28 \mathrm{kDa}$, but not the $56 \mathrm{kDa}$, polypeptides were closely linked in the native protein. Of several mAbs directed against the $28 \mathrm{kDa}$ polypeptide, one, designated CP11, both inhibited and captured the active enzyme, indicating that this polypeptide is an integral part of the urease. None of the mAbs directed against the $56 \mathrm{kDa}$
Fig. 6. Indirect immunogold-labelling of urease antigen at the ultrastructural level with mAb CP11. (a) Bacteria were prefixed with glutaraldehyde and incubated with CP11. Bound antibody was detected by incubation with goat anti-mouse IgG coupled to $10 \mathrm{~nm}$ gold particles. Labelled bacteria were negatively stained with phosphotungstic acid. Note the location of the urease antigen on the surface of the bacteria, particularly in the loose surface-associated material. Bar, $0.5 \mathrm{~nm}$. (b) Unfixed bacteria were infused with sucrose solution then frozen in liquid nitrogen for ultrathin cryosections $(500 \mathrm{~nm})$. The sections were incubated with $\mathrm{mAb}$ CP11 and bound antibodies were detected as in (a). The sections were then mounted in methylcellulose and stained with uranyl acetate. Note that the use of unfixed bacteria and methylcellulose mountant in this procedure did not allow the morphological clarity normally observed with fixed, plasticembedded bacteria. However, intracellular antigenicity is preserved and detectable. The urease antigen in these sections was located on the extracellular surface of the bacterial membrane. Bar, $0.5 \mu \mathrm{m}$. protein, however, demonstrated anti-urease activity. Unfortunately, no antibodies directed against the $61 \mathrm{kDa}$ polypeptide were produced, although this component appears to be immunogenic in the hyperimmunized rabbit (Newell, 1987b) and humans during infection (Newell, 1987a).

Our results are consistent with recent molecular biological evidence from Clayton et al. (1989a) and Labigne-Roussel \& Courcoux (1989). Both groups have apparently cloned the urease gene of $H$. pylori. The former group achieved expression in $E$. coli of inactive urease which was found to comprise the $61 \mathrm{kDa}$ and $28 \mathrm{kDa}$ polypeptides. Moreover, mAb CP11 immunolabelled the $E$. coli-expressed $28 \mathrm{kDa}$ polypeptide (Clayton et al., 1989b). The latter workers have obtained active urease expression in Campylobacter jejuni. These molecular biological studies once again suggest that the $56 \mathrm{kDa}$ polypeptide is irrelevant to enzyme activity, and is probably merely co-purifying with the urease when separated by size exclusion gel filtration. One possibility was that the $56 \mathrm{kDa}$ polypeptide was equivalent to the $51 \mathrm{kDa}$ flagellin polypeptide identified by Geis et al. (1989). However, preliminary investigations comparing the urease-containing fractions, from the flagellated wild-type strain, and an aflagellate variant, indicate that the $56 \mathrm{kDa}$ polypeptide is still present despite the absence of flagella. Moreover, the $56 \mathrm{kDa}$ polypeptide and purified flagella (kindly provided by Dr Geis, Ruhr University, Bochum, FRG) do not have the same electrophoretic mobility (D. G. Newell, unpublished observations).

The identity and role of the doughnut structures found in fraction 14 is unknown. These structures are considered to be an integral component of the outer membrane (Newell, 1987a; Jones et al., 1985) and the 
possibility remains that they are either associated with the urease or the $56 \mathrm{kDa}$ polypeptide.

The mAb CP11 has been used to locate the enzyme on the organism. For the enzyme to be effective in protecting $H$. pylori from the acid microenvironment of the stomach, it would be expected to be expressed on the bacterial surface. The ultrastructural localization of the enzyme by immunogold-labelling demonstrated that the urease is, indeed, surface-exposed, which would allow the urea substrate to be hydrolysed extracellularly. The urease-containing material appears to be loosely bound to the surface of $H$.pylori (Fig. $6 a$ ) and may, therefore, be continually shed, thereby presenting an antigenic challenge to the gastric mucosa. The relationship of this antigenic insult to $H$. pylori-associated gastritis remains to be investigated.

\section{Addendum}

In a recent publication $\mathrm{Hu} \&$ Mobley (1990) have purified urease by chromatographic techniques and confirmed that the enzyme comprises two polypeptide subunits of $66 \mathrm{kDa}$ and $29.5 \mathrm{kDa}$.

\section{References}

BLASER, M. J. (1987). Gastric campylobacter-like organisms, gastritis and peptic ulcer disease. Gastroenterology 93, 371-383.

Clayton, C. L., Wren, B. W., Mullany, P., Topping, A. \& TABAQCHALI, S. (1989a). Molecular cloning and expression of Campylobacter pylori species-specific antigens in Escherichia coli K12. Infection and Immunity 57, 623-629.

Clayton, C. L., Topping, A. J., Kleanthous, H., Wren, B. W., Mullany, P. \& TABAQCHali, S. (1989b). Molecular cloning and characterization of Campylobacter pylori species-specific antigens in Escherichia coli K12. In Gastroduodenal Pathology and Campylobacter pylori, pp. 115-118. Edited by F. Megraud \& P. Lamoulliatte. Amsterdam: Elsevier Science Publishers BV.

Dunn, B. E., Perez-Perez, G. J. \& Blaser, M. J. (1989). Two dimensional gel electrophoresis and immunoblotting of Campylobacter pylori proteins. Infection and Immunity 57, 1825-1833.
Geis, G., Leying, H., Suerbaum, S., Mai, U. \& Opferkuch, W. (1989). Ultrastructure and chemical analysis of Campylobacter pylori flagella. Journal of Clinical Microbiology 27, 436-441.

HAzell, S. L. \& LeE, A. (1986). Campylobacter pyloridis, urease, hydrogen ion back diffusion, and gastric ulcers. Lancet ii, 15-17.

Hu, L.-T. \& Mobley, H. L. T. (1990). Purification and N-terminal analysis of urease from Helicobacter pylori. Infection and Immunity 58, 992-998.

JOHNSTONE, A \& THORPE, R. (1987). Immunochemistry in Practice, 2nd edn. Oxford: Blackwell Scientific Publications.

JONES, D. M., CURRY, A. \& FoX, A. J. (1985). An ultrastructural study of the gastric campylobacter-like organism 'Campylobacter pyloridis'. Journal of General Microbiology 131, 2335-2341.

LABIGNe-Roussel, A. \& CourCouX, P. (1989). Cloning and expression of the urease genes of Campylobacter pylori. In Gastroduodenal Pathology and Campylobacter pylori, pp. 119-122. Edited by F. Megraud \& P. Lamoulliatte. Amsterdam: Elsevier Science Publishers BV.

Lambden, P. R., Heckels, J. E., James, L. T. \& WatT, P. J. (1979). Variations in surface protein composition associated with virulence properties in opacity types of Neisseria gonorrhoeae. Journal of General Microbiology 114, 305-312.

MCBride, B. W. \& Newell, D. G. (1989). Production and characterization of monoclonal antibodies directed against guinea pig IgG subclasses. Journal of Immunological Methods 118, 193-198.

Marshall, B. J., Barrett, L. J., Prakesh, C., McCallum, R. W. \& GuERRANT, R. L. (1988). Protection of Campylobacter pyloridis (CP) but not Campylobacter jejuni (CJ) against acid susceptibility by urea. In Campylobacter IV (1987), pp. 402-403. Edited by B. Kaijser \& E. Falsen. Gothenburg: University of Gothenburg.

Mobley, H. L. T., Cortesia, M. J., Rosenthal, L. E. \& Jones, B. D. (1988). Characterization of urease from Campylobacter pylori. Journal of Clinical Microbiology 26, 831-836.

Newell, D. G. (1987a). Human serum antibody responses to the surface protein antigens of Campylobacter pyloridis. Serodiagnosis and Immunotherapy 1, 209-217.

NEWELL, D. G. $(1987 b)$. Identification of the outer membrane proteins of Campylobacter pyloridis and antigenic cross-reactivity between $C$. pyloridis and C. jejuni. Journal of General Microbiology 133, 163-170.

NewELL, D. G. \& RATHBone, B. J. (1989). The serodiagnosis of Campylobacter pylori infection. Serodiagnosis and Immunotherapy 3, $1-6$.

Newell, D. G., McBride, H. and Pearson, A. D. (1984). The identification of outer membrane proteins and flagella of Campylobacter jejuni. Journal of General Microbiology 130, 1201-1208.

NeWEll, D. G., McBride, B. W. \& ClaRK, S. (1988). Making Monoclonals. London: Public Health Laboratory Service.

Precious, B. L., Thirkell, D. \& Russell, W. C. (1987). Preliminary characterization of the urease and a $96 \mathrm{kDa}$ surface-expressed polypeptide of Ureaplasma urealyticum. Journal of General Microbiology 133, 2659-2670.

SkIRrow, M. B. (1977). Campylobacter enteritis: a 'new' disease. British Medical Journal 2, 9-11. 